\title{
E-TELECOMMUNICATION INFORMATION SYSTEM
}

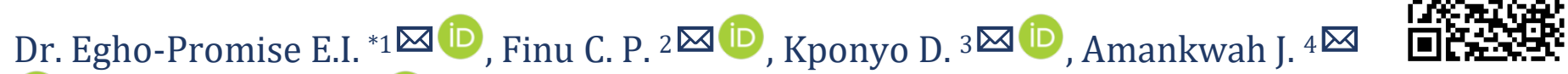

(iD), Adu Mensah S. 5 四 (iD)

${ }^{* 1}$ Regional Technical Head, Glo Mobile Ghana Limited, Tamale, Ghana

2 Managing Partner, 2P Media.Net, Accra, Ghana

3, 4, 5 Department of Computer Science, FAST, Koforidua Technical University, Koforidua, Ghana

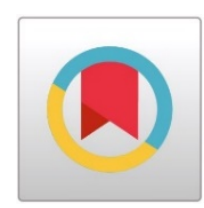

DOI: https://doi.org/10.29121/granthaalayah.v8.i8.2020.1181

Article Type: Research Article

Article Citation: Dr. Egho-Promise E.I., Finu C. P., Kponyo D., Amankwah J., and Adu Mensah S.. (2020). E-TELECOMMUNICATION INFORMATION SYSTEM. International Journal of Research GRANTHAALAYAH, 8(8), 403-142. https://doi.org/10.29121/granthaa layah.v8.i8.2020.1181

Received Date: 16 August 2020

Accepted Date: 31 August 2020

Keywords:

Telecommunication

Access Network

Core Network

Transmission System

MTTR

\section{ABSTRACT}

The transmission of traffic either in form of voice or data from a source to destination over a transmission media such as fiber cable or digital microwave radio is termed telecommunication.

The telecommunication is classified into three categories namely: Access network, core network and transmission system. The access network directly provides network services to the subscribers. The core network does the routing or switching of traffic from the source to destination over the transmission media while the transmission system provides the media through which the traffic is transmitted from source to the destination.

In this study, an automated web-based application name an ETelecommunication Information System (ETIS) will be designed and developed to provide accuracy and consistence of network data, reduce Mean Time To Restore (MTTR) faulty equipment, increase revenues from cell sites and improve customers satisfaction in the telecommunication industry.

Qualitative research approach and qualitative research method will be adopted so as to achieve reliable objectives of the system.

\section{INTRODUCTION}

Access network which is one of the categories of the telecommunication network enables subscribers to access network services provided by telecom operators. These services include but not limited to recharging of phones with credits, checking of balances, making voice and video calls, sending messages, sending and receiving ecash, online banking transactions, ecommerce, etc. Without access network, telecom subscribers will not be able to access any of these services.

Cell site which can also be referred to as base station is any telecom location which contains transceiver and power equipment that enables traffic to be transmitted and received on mobile phones or any other electronics devices that can store and process data. In some cases, it comprises of core network equipment also.

If the access network is out of service or there is failure in either core network or transmission system, subscribers will not be able to access network services and this will lead to loss of revenues to the service provider and decrease in customers satisfaction.

(C) 2020 The Author(s). This is an open access article distributed under the terms of the Creative Commons Attribution License, which permits unrestricted use, distribution, and reproduction in any medium, provided the original author and source are credited. 
In this study, the Electronic Telecom Information System (ETIS) will be designed and developed to address these problems associated with Telecommunication Network operators

\subsection{PROBLEM STATEMENT}

Customers often get dissatisfied of services provided by telecom network providers and this incident leads to reduction in revenues from such the telecom cell sites.

\subsection{OBJECTIVES OF THE STUDY}

1) To improve customer satisfaction

2) To provide reliable, consistent and accurate network information for decision making

3) To increase revenues from telecom cell sites

\subsection{SIGNIFICANCE}

The electronic telecom information system will provide efficient means of processing and storing data from various cell sites, improve customers satisfaction and increase telecom service provider revenues.

\section{LITERATURE REVIEW}

Telecommunication began with telegraphs and not telephones as seen today (Eric, Eng. \& Eng., 2008). According to Statista (2020), telecommunication is an economic booster.

Among the three categories of telecommunication, it is the access network which directly interfaces with the subscribers and enable them to access different types of network services (Stronkowsky,2017). There is often inaccuracy and inefficiency when cell sites data are recorded in spreadsheet document. A lot of time is spent locating specific records in the spreadsheet application and decision making with respect to network health improvement is delayed. If this happen, the Mean Time To Restore (MTTR) faulty network equipment at cell sites increases. The MTTR is the average time taken to fix faulty equipment.

In this study, the Electronic Telecommunication Information System (ETIS) will address these challenges.

\subsection{ELEMENTS OF ACCESS NETWORK}

The followings are the components of access network in mobile telecommunication network:

1) Base Station Subsystem (BSS): This is $2 \mathrm{G}$ access network which encompasses BTS and BSC. Transcoder is included in some access networks.

2) Base Transceiver Station (BTS): It manages the radio resources such as physical channel (time slots) and serves as an interface between the MS and the BSC. It supports one or more sectors

3) Base Station Controller (BSC): It establishes connections between the Pause Code Modulation (PCM) and the radio channels on the air interface and also manages a BTS or several BTSs. It interfaces with Mobile Switching Center (MSC) and Serving GPRS Support Node (SGSN) for data services.

4) Radio Network System (RNS): It is the 3G access network and it comprises of RNC and NodeB equipment.

5) Radio Network Controller (RNC): It interfaces with the SGSN, Media Gateway (MGW) and Core Server (CS) for data services. It communicates and manages one or several Node B

6) NodeB(NB): It manages the radio resources and supports one or more sectors.

7) Mobility Management Entity (MME): It performs handle over operations both intra and inter in Long Term Evolution (LTE) network. It allocates temporary subscriber identity.

8) Evolved Node B: (eNB): In 4G access network, it performs user plane routing to the Serving Gateway. It compresses Internet Protocol header and performs data encryption

9) Mobile Station (MS): It is a collection of MS and SIM. Subscriber Identity Module (SIM) is the microchip that stores subscriber data. The MS enables telecommunication subscribers to gain access to different network services on phones. 


\subsection{EXISTING SYSTEM}

Telecom access network operations personnel lose motivation due to the tedious and repetitive nature of the manual operational processes (Tandon, 2018). There is inaccuracy and duplication of data when data from cell sites are processed and stored in spreadsheet. A lot of time is spent searching for specific network records among thousands of records in the excel documents. Because of this delay, if a cell site is out of service, the time to restore it is also affected.

\subsection{PROPOSED SYSTEM}

The proposed system is Electronic Telecommunication Information System (ETIS). It is automated web- based application which will be designed and developed to overcome inefficiency in processing of network data, eliminate data redundancy and inaccuracy of data in the manual system.

The ETIS application will be hosted on the internet server and can be accessed on a mobile phone or a computer system. The system will capture network data such cell sites locations, microwave radio and fiber status, fiber cuts, network faults and staff job activities. Faults detected in the network will be immediately resolved by the field engineers as result of the available access to such data on the server.

\section{METHODOLOGY}

Qualitative research approach will be adopted in this study and is basically an open-ended approach that does not involve hypothesis but gives in depth insight into problems (Bhandari,2020). Qualitative research method will be implemented specifically interview.

\subsection{DATA COLLECTION INSTRUMENT}

Interview will be used to collect data from different telecom subscribers. The instrument is chosen to gather data because is a conversation base research method.

\subsection{AGILE MODEL}

Agile is a very common software development life cycle model and it will be used in developing the proposed system because of its speedy and elastic response to changes.

The figure 1 below shows the different phases in agile model.

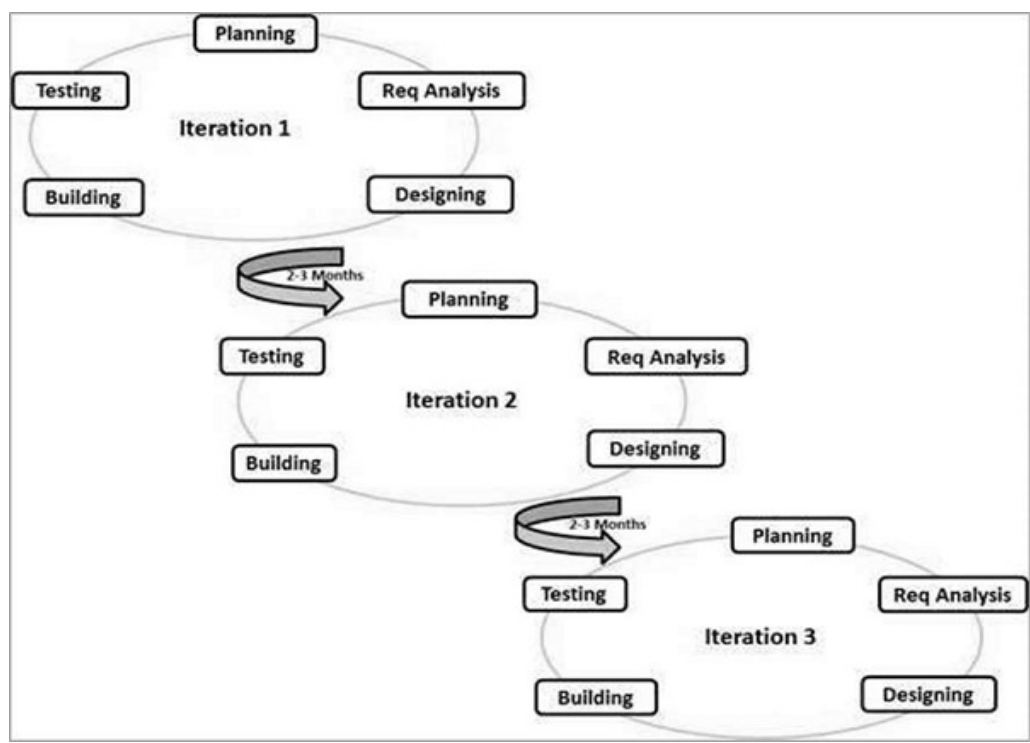

Figure 1: Agile model phases 
Agile Model comprises of the following phases: planning, requirement analysis, designing, building and testing.

\subsection{BENEFITS OF AGILE MODEL}

1) Changes in requirements can easily be executed in the system

2) Comparing it with waterfall model, only few planning activities are needed in order to start development of the software.

\subsection{USE CASE DIAGRAM}

The use case diagram below illustrates the interaction between the proposed system and the users.

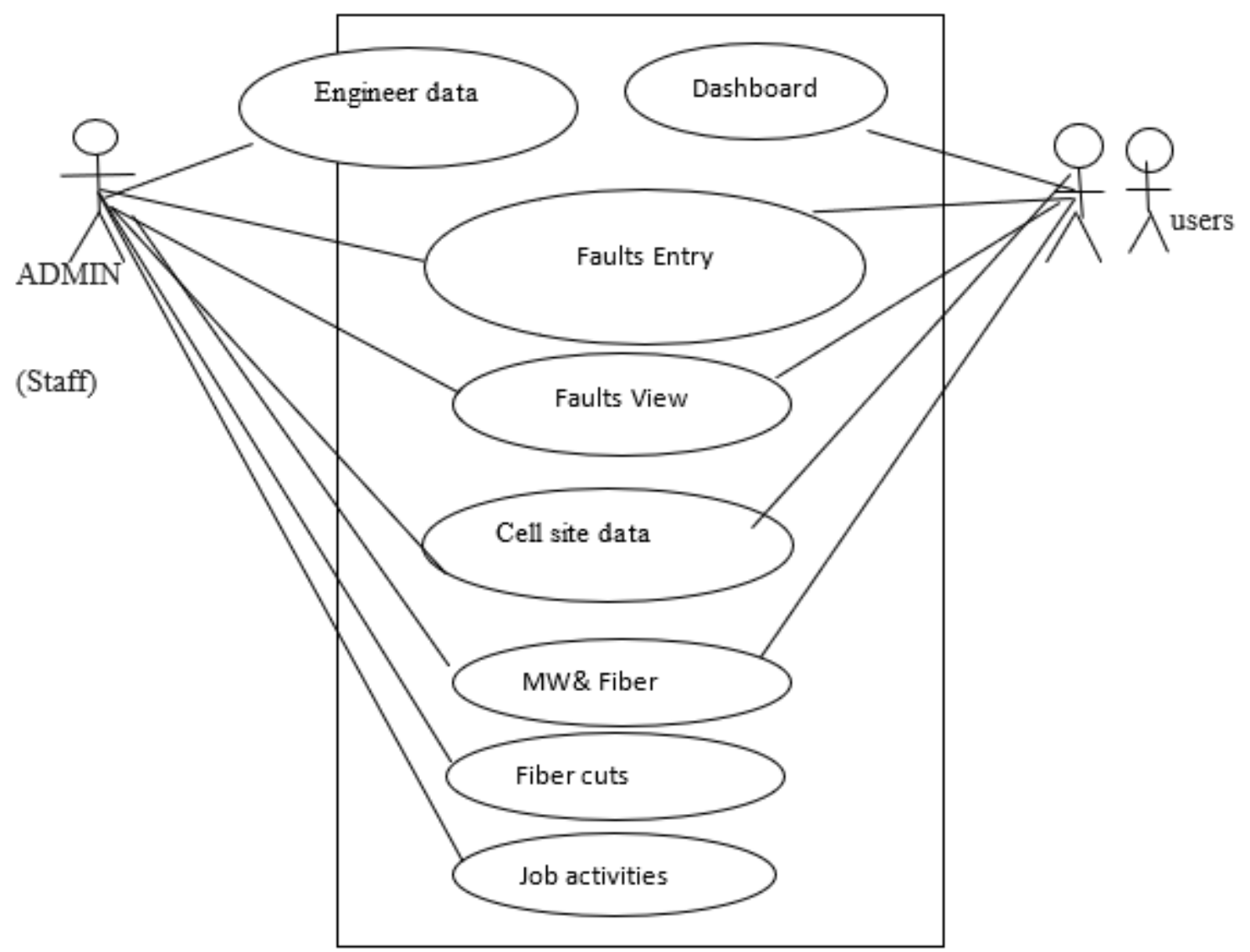

Figure 2: Use case diagram of the proposed system

\subsection{SOFTWARE DESIGN TOOL}

Flow chart tool will be used in the design of the proposed ETIS. The below flowchart shows the logical and pictorial representation of the proposed system. 
Dr. Egho-Promise E.I., Finu C. P., Kponyo D., Amankwah J., and Adu Mensah S.

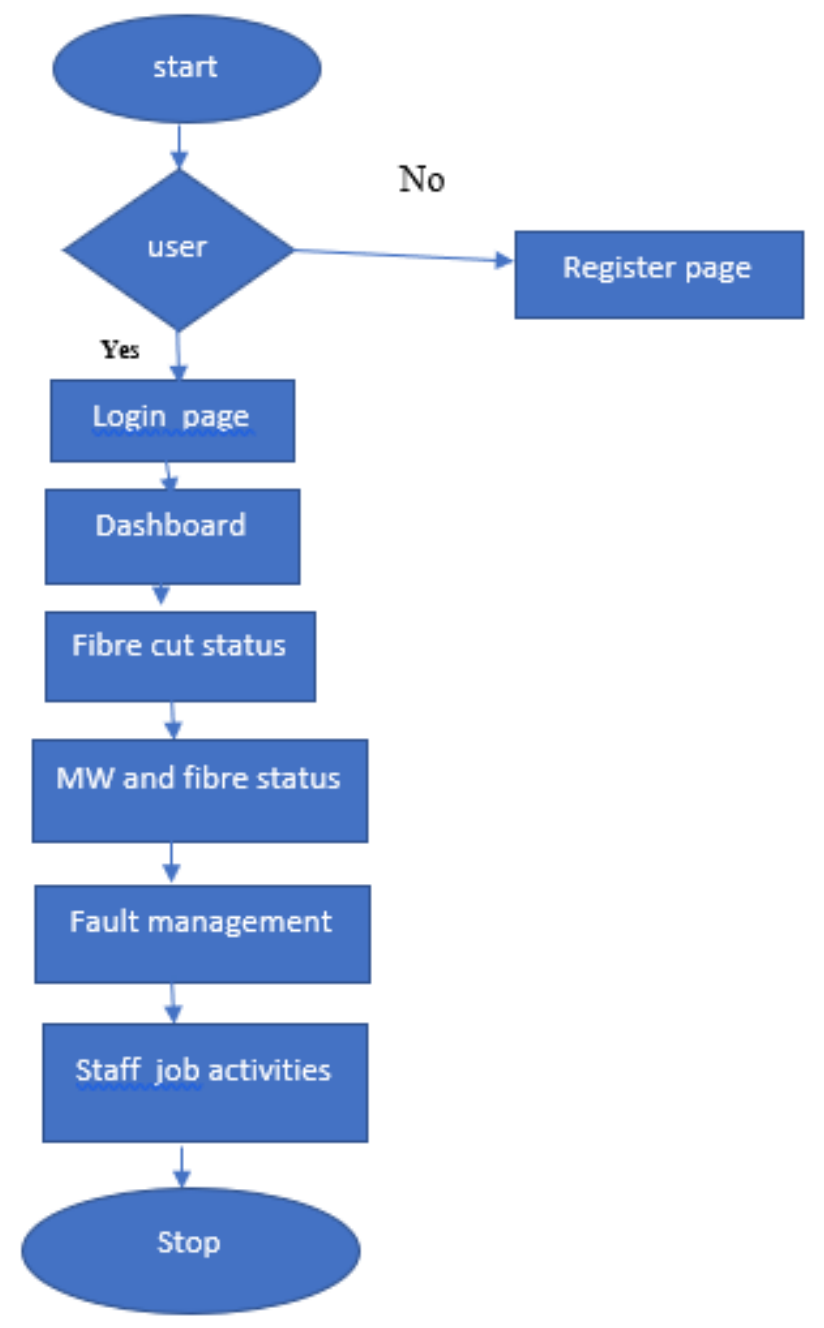

Figure 3: Flow chart diagram of the proposed system

\subsection{PROGRAMMING TOOLS}

The programming language tools in developing the proposed system are: HTML, PHP, CSS, Bootstrap and JavaScript.

\section{EXPERIMENTAL RESULTS AND DATA ANALYSIS}

\subsection{SOURCE CODES OF THE SYSTEM}

The codes below give access to users to the dashboard which display other interfaces.

$<$ ?php

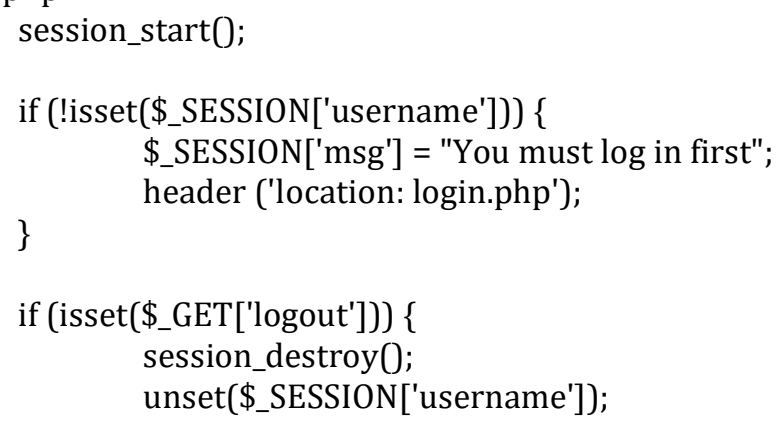


header("location: login.php");

?>

$<$ !DOCTYPE html>

$<$ html $>$

$<$ head $>$

$<$ title $>$ Home $</$ title $>$

$<$ link rel="stylesheet" type="text/css" href="style.css">

$<$ head $>$

$<$ body $>$

$<$ div class="header" $>$

$<\mathrm{h} 2>$ ETIS $</ \mathrm{h} 2>$

$</$ div $>$

$<$ div class="content" $>$

$<$ !-- notification message -->

$<$ ?php if (isset(\$_SESSION['success'])) : ?>

$<$ div class="error success" $>$

$<\mathrm{h} 3>$

$<$ ?php

echo \$_SESSION['success'];

?>

unset(\$_SESSION['success']);

$</ \mathrm{h} 3>$

$</$ div $>$

$<$ ?php endif ?>

$<!--$ logged in user information -->

$<$ ?php if (isset(\$_SESSION['username'])) : ?>

$<$ div style=" display:flex; align-items:center; justify-content: center;">

$<$ p $>$ Welcome $<$ strong $><$ ?php echo \$_SESSION['username']; ? $><$ /strong $></$ p $></$ div $>$

$<$ p $><$ a href="ETIS/index.html?logout='1'" style="color: red; display:flex; align-items:center; justify-

content: center; ">GO TO DASHBOARD $</ \mathrm{a}></ \mathrm{p}>$

$<$ ?php endif ?>

$</$ div $>$

$</$ body $>$

$</$ html $>$

\subsection{SOFTWARE TESTING}

After the software was developed, different tests were done to ascertain the usability and reliability of the system as shown below.

Table 1: shows the results of the tests carried out in the system

\begin{tabular}{|c|c|c|c|}
\hline TEST & CONDITION & ACTION & RESULTS \\
\hline $\begin{array}{c}\text { Add Site } \\
\text { test 1 }\end{array}$ & Site ID and Site location are empty & Site added & $\begin{array}{c}\text { Site process failed. } \\
\text { Reason: empty fields }\end{array}$ \\
\hline $\begin{array}{c}\text { Add Site } \\
\text { test 2 }\end{array}$ & BTS Type and Site status not selected & $\begin{array}{c}\text { Save Site button } \\
\text { initiated. } \\
\text { Please all fields are } \\
\text { required }\end{array}$ & $\begin{array}{c}\text { Site processes cancelled. } \\
\text { Add Site } \\
\text { test 3 }\end{array}$ \\
\hline $\begin{array}{c}\text { Add Staff } \\
\text { test 1 }\end{array}$ & $\begin{array}{c}\text { Staff name empty, Staff ID empty, Staff email } \\
\text { empty }\end{array}$ & $\begin{array}{c}\text { Add Staff button } \\
\text { initiated }\end{array}$ & $\begin{array}{c}\text { Error: please all field are } \\
\text { required }\end{array}$ \\
\hline
\end{tabular}

International Journal of Research -GRANTHAALAYAH 
Dr. Egho-Promise E.I., Finu C. P., Kponyo D., Amankwah J., and Adu Mensah S.

\begin{tabular}{|c|c|c|c|}
\hline $\begin{array}{c}\text { Add Staff } \\
\text { test } 2\end{array}$ & Staff name and Staff ID valid & $\begin{array}{c}\text { Add Staff button } \\
\text { initiated }\end{array}$ & $\begin{array}{c}\text { Error: please all fields are } \\
\text { required }\end{array}$ \\
\hline $\begin{array}{c}\text { Add Staff } \\
\text { test } 3\end{array}$ & Staff name, ID, phone number, email and all \\
fields entered. & $\begin{array}{c}\text { Add Staff button } \\
\text { initiated }\end{array}$ & Staff added successfully \\
\hline
\end{tabular}

Table 1: Test results

\subsection{SYSTEM INTERFACES}

Figures 4 to 10 are the system interfaces showing different uses as explained below.

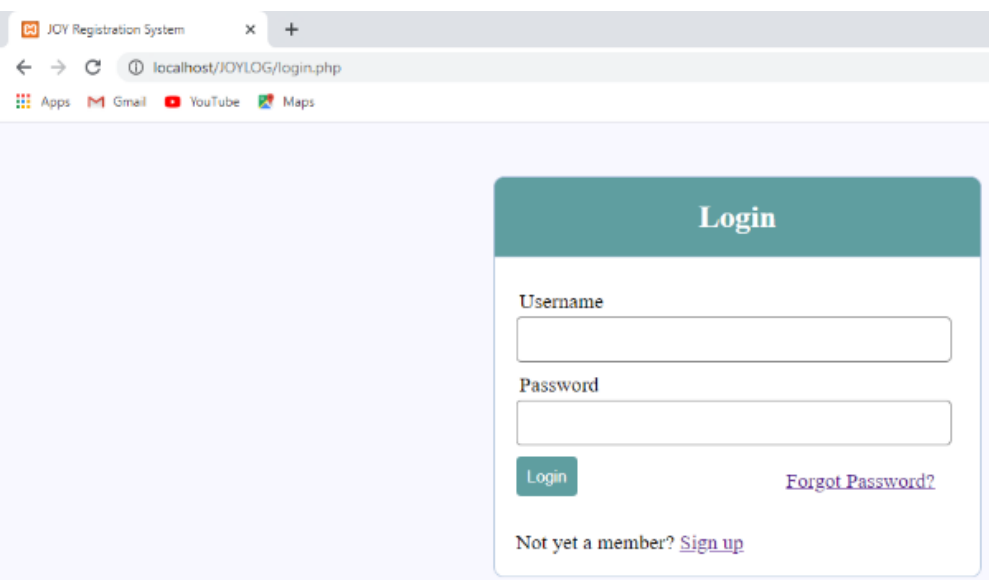

Figure $\overline{4:}$ above is the login interface which display the login page, where authorized users can enter their username and password for authentication before accessing the system.
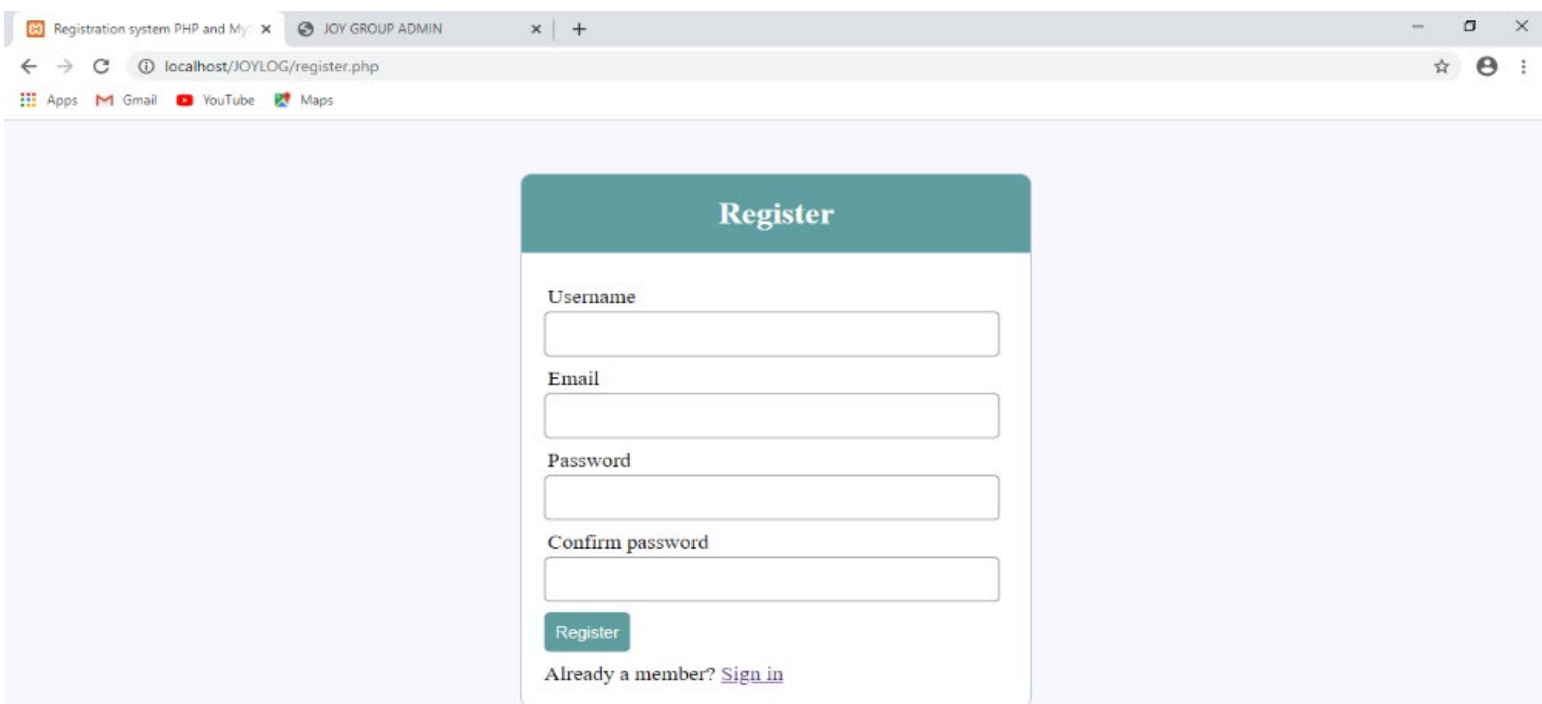

Figure 5: above, is the register interface which show the form a new user must fill to create accounts before accessing the system. 


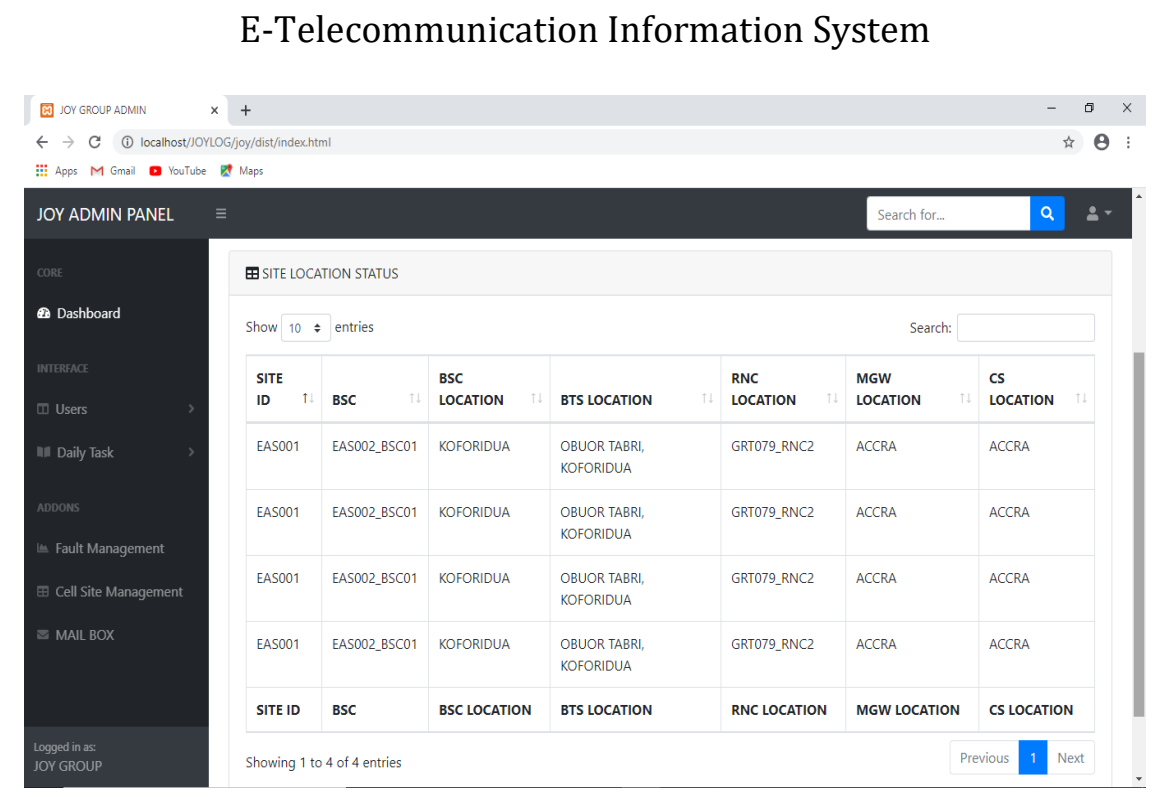

Figure 6: above shows Sites ID, BSC, BSC location, BTS location, RNC location, MGW location and CS location. The user must enter the cell sites data and this will be processed by the system to generate reports for decision making.

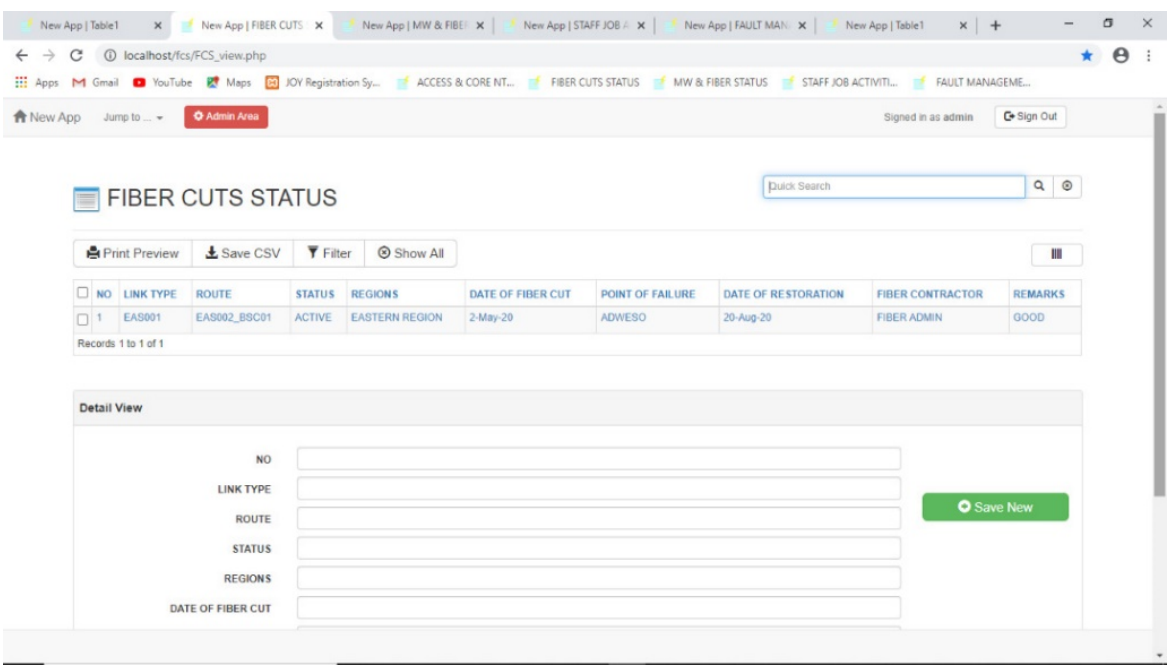

Figure 7: above shows the link type, route of fiber, region, date of fiber cut, point of failure, date of restoration and remarks.

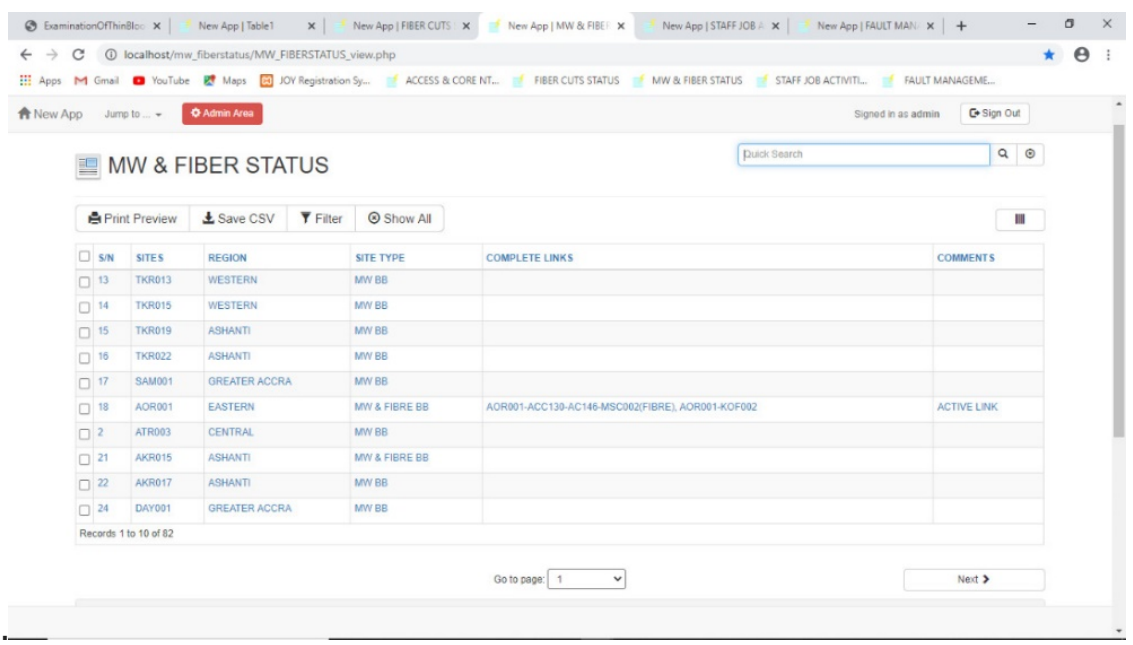

Figure 8: above displays the microwave radio and fiber status of different cell sites. 
Dr. Egho-Promise E.I., Finu C. P., Kponyo D., Amankwah J., and Adu Mensah S.

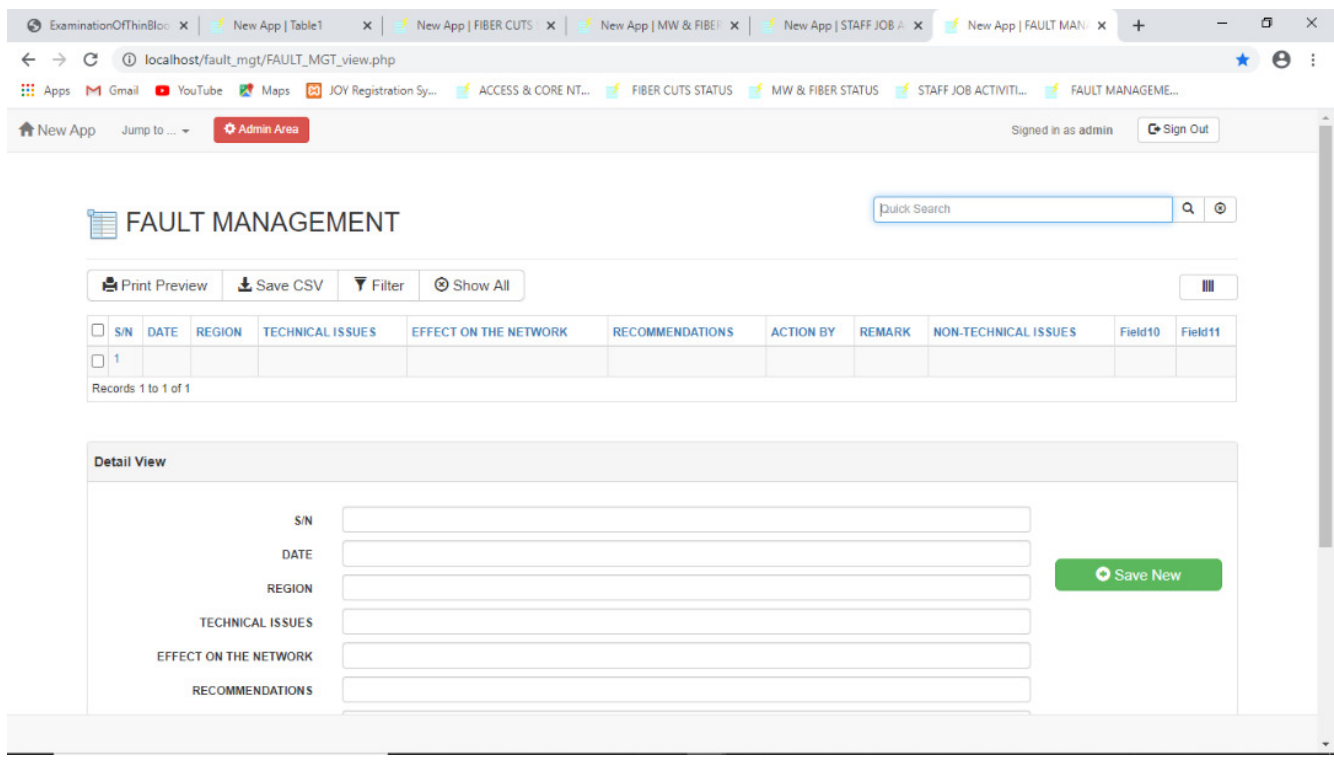

Figure 9: above shows the different faults on the network and their status.

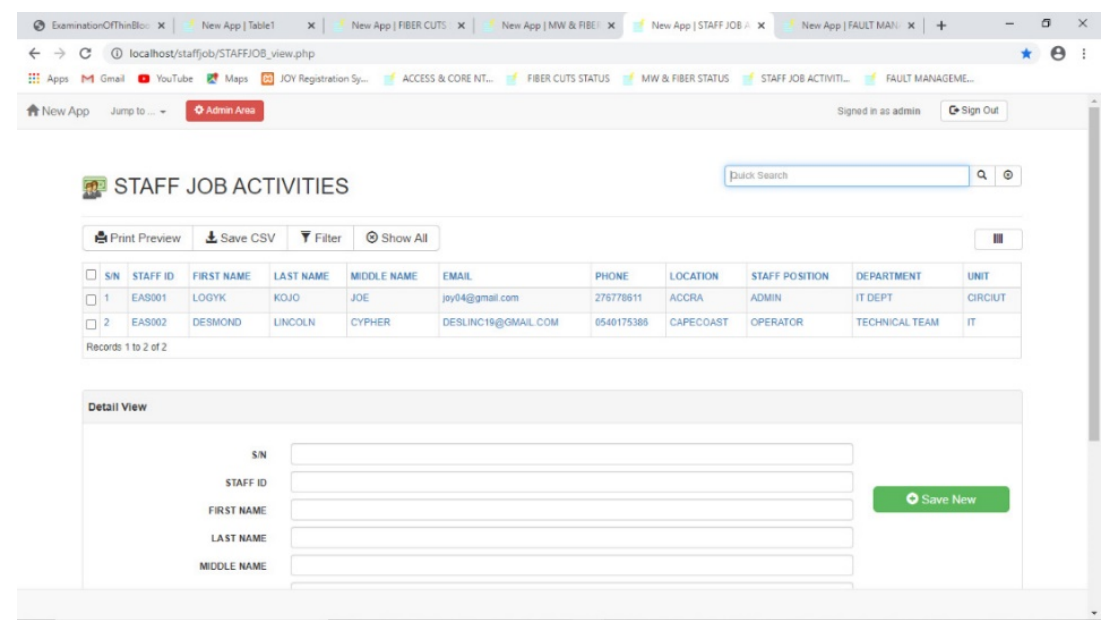

Figure 10: above shows the different activities performed by the network operations and maintenance staff.

\section{CONCLUSION AND RECOMMENDATION}

\subsection{CONCLUSION}

The results above showed that we have been able to develop usable and reliable Electronic Telecommunication Information System (ETIS) which can improve customers satisfaction, reduce Mean Time To Resolve (MTTR) faults and thereby increasing revenues from cell sites for telecom network services providers. The result also showed consistence and accuracy of information resulted from cell sites data that were processed.

\subsection{RECOMMENDATION}

It is recommended that the system should be implemented to replace the manual system of using spreadsheet to record and process network data because of its benefits mentioned above otherwise if it is not adopted, the MTTR faulty equipment will always be high, customers satisfaction will decline and revenues from cell sites will also decrease. 


\section{SOURCES OF FUNDING}

This research received no specific grant from any funding agency in the public, commercial, or not-for-profit sectors.

\section{CONFLICT OF INTEREST}

The author have declared that no competing interests exist.

\section{ACKNOWLEDGMENT}

None.

\section{REFERENCES}

[1] Coll, E.C., Eng, M., Eng, P. (2008). Telecom 101.Canada: Teracom Training Institute Ltd

[2] O'Dea, S. (2020, February 28). Forecast of worldwide Fixed telecom spending from 2015 to 2020. Statista. Retrieved from https://www.statista.com/statistics/308603/worldwide-fixed-telecom-spending-forecast/

[3] Stronkowsky, K.J. (2017, September 18). Enhancing passive optical networks with structured cabling. Cabling \& Installation Maintenance. from https://www.cablinginstall.com/cable/fiber/article/16469306/enhancing-passive-optical-networks-withstructured-cabling

[4] Tandon, A. (2018, August 31). Automation and Intelligence in network operations. Developing Telecoms. Developing Telecom. Retrieved from https://www.developingtelecoms.com/business/reports-whitepapers/8011-automation-intelligience-in-network-operations.html

[5] Bhandari, P. (2020, July 30). Methodology. Scribbor. Retrieved from https://www.scribbr.com/methodology/qualitative-research/ 